\title{
Evaluation of some mango seedling strains grown under Aswan region
}

\author{
Hamad, A.S.A. \\ Tropical Fruits Department, Horticulture Research Institute, ARC, Egypt
}

\begin{abstract}
This study was established during two consecutive seasons of 2019 and 2020 in a private mango orchard situated at KomOmbo, Aswan Governorate (24 28' 45.1596" and 32 $56^{\circ}$ '28.626") where the texture of soil is clay and water table depth not less than two meters. Fifteen mango seedling strains age of trees ranging from 25 to 30- years old. They were planted at $6 \times 6$ meters; regular horticultural practices were carried out as usual. The growth, nutritional status, yield and quality of fruits of fifteen mango seedling strains were evaluated under conditions of Aswan region based on relatively better yield and fruit quality. The following strains of mango seedlings have been cultivated successfully, thirteenth, twelfth, eleventh and tenth strain in descending order under Aswan conditions. Also, through the numerical evaluation of the productivity characteristics and the fruit quality of the strains under study, it became clear that the tenth, eleventh, twelfth and thirteenth strains showed superiority, so they must be cultivated and spread them through vegetative propagation and expand their cultivation.
\end{abstract}

Keywords: Mango seed strains; Growth; Yield; Quality; Numerical evaluation

\section{Introduction}

The botanical name for mango tree is Mangifera indica mango belongs to the Anacardiaceae family. The genus mangifera is native to South- East Asia and includes 62 species. Mango has great adaptability and thrives in a wide range soil and climatic conditions. Also, it has relatively hardly nature, low cost of culture and maintenance. Mango is the most popular fruit of the orient and has been called king of the fruits. Fruits from the better cultivars have melting yellow flesh, fine aroma and good flavour. Ripe mangoes are eaten in dessert canned or used for making juice, Jam and other preserves. The fresh kernel of the mango seed (stone) constitutes 13-19\% of

\footnotetext{
*Corresponding author: A.S.A. Hamad

Email: saberali.77@yahoo.com

Received: March 18, 2021;

Accepted: April 8, 2021;

Published: April 9, 2021.
}

weight of the fruit, $55-70 \%$ of the weight of the stone. In times of food scarcity in India, the kernels are roasted or boiled and eaten after soaking to dispel the astringency (tannins), the kernels are dried and ground to flour which is mixed with wheat or rice flour to make bread and it is also used in puddings. Indian analyses of the mango kernel reveal the amino acids namely alanine, cystine, arginine, glycine, aspartic acid, glutamic acid, histidineleucine, lysine, Isoleucine, methionine, praline, serine, phenyl alanine, tyrosine, threanine, tyrosine valine at levels lower than in wheat and gluten. Tannin content may be 0.12 to $0.18 \%$ or much higher in certain mango cultivars. (Singh, 1960 and Galan- Sauco, 1993; Larrauriet al., 1996 and Kuruom, 1967). Mangoes are cultivated in more than 100 countries especially India, Pakistan, Mexico, Philippines, Brazil, China, Bangladesh and Other countries of south East 
Asia, India has the largest mango cultivation area (Singh, 1960; Whiley, 1992; Whiley and Scaffer, 1997 and Devillers, 1998). It is also grown successfully in Egypt in the most regions. In Egypt, mango is considered among the principle and strategic fruit crops and it considered among the principle and strategic fruit crops and it ranks the second position after citrus. The fruiting area of mango orchards reached 265509 feddans produced 1091535 tons fruits. In Aswan Governorate where the present study took place fruiting area reached 13573 feddans produced 67076 tons fruits. (Annual Reports of Statistical Institute and Agricultural Economic Research in Egypt, 2019). Therefore, the aim of this study was an attempt to know more about growth, nutritional status oftrees, fruit setting, yield, fruit quality and the susceptibility of fifteen mango seedy strains growing in Aswan region. This assessment could provide valuable information to prescribe the prime mango seedling strain having higher yield and fruit quality which can be cultivated successfully under Upper Egypt environmental conditions.

\section{Materials and Method}

This study was established during two consecutive seasons of 2019 and 2020 in a private orchard situated at KomOmbo. Aswan governorate where the texture of the soil is clay with a water table depth not less than two meters. Some mango seedling strains namely first, second, a third, fourth, fifth, sixth, seventh, eighth, ninth, tenth, eleventh, twelfth, thirteenth, fourteenth and fifteenth strain were selected for achieving this evaluation study. All mango seedling strains have the age of trees ranging from 25 to 30 years old at the start of this study. They were planted at $6 \times 6$ meters apart (116 trees/ feddan). Each strain was represented by six trees which were healthy and uniform in growth vigor. The fifteen treatments consisted of the six tested mango seedling strains which examined. This experiment was arranged in randomized complete block design (RCBD) with three replicates, two trees per each. All mango seedling strains received a basal recommended fertilizer in addition to the regular agricultural and horticultural practices which were already followed in the orchard including pruning, hoeing, irrigation with Nile water as well as pathogens, pests and weed control. Fifteen leaves from spring growth cycle were chosen on four labeled branches (four shoot, for each direction) for measuring the main shoot length, number of leaves per shoot and leaf area according to (Ahmed and Morsy, 1999). Samples of five mature and fresh leaves / tree were taken (first week of July) for determination of total chlorophylls (chlorophyll A + B) and total carotenoids (mg/ 1.0 g. F.W.) according to (Fadl and Seri ElDeen, 1978). Fifteen mature leaves from nonfruiting shoots in the spring growth cycle (Summer, 1985) were taken (first week of July) for determination of N, P, K (as \%) and $\mathrm{Zn}$ and $\mathrm{Fe}$ (as ppm) according to the procedures that outlined by (Chapman and Pratt, 1965). Ten panicles per tree were chosen and labeled four counting number of perfect flowers. Just before harvesting, number of retained fruits on the ten selected panicles/tree was counted percentages of initial fruit setting and fruit retentions $\%$ was estimated by dividing the number of retained fruits / ten panicles by total number of flowers on these panicles and multiplying the product by 100 . The fifteen strains were harvested during July and August during both seasons. Yield per tree (expressed as number of fruits / tree and weight (kg.) / tree was recorded. Ten fruits from each tree were taken for determination the following physical and chemical character.

\section{1- Fruit weight (g.)}


2- Fruit height (cm.)

3- Fruit diameter $(\mathrm{cm}$.

4- Percentage of peel weight.

5- Percentage of seed weight.

6- Percentage of pulp weight

7- T.S.S. \% by using handy refractometer.

8- Percentages of total and reducing sugars (A.O.A.C., 2000) according to (Lane and Eynon, 1965).

9- Total acidity \% (as g citric acid/ $100 \mathrm{~g}$ pulp) (A.O.A.C., 2000).

10-Crude fibre content (A.O.A.C., 2000).

All the obtained data were tabulated and statistically analyzed according to the procedure of (Steel and Torrie, 1980). The individual comparisons on the studied parameters in the fifteen-mango seedling strain were compared by using new L.S.D. test at $5 \%$.

\section{Numerical evaluation of the mango seed strains}

Evaluation of the tested mango strains at the average 2019 and 2020 seasons was calculated on the basis of 100 units which were divided among the various fruit parameters according to (Hamed, 2012).30 units for the yield/tree, 10 units for each of the fruit weight, percentage of fruit set, percentage of pulp and total sugars, and 10 units for each of the characteristics of fruit length and width, seed weight, TSS\%, acidity $\%$ and crude fiber $\%$. Each strain that gave the best results in any character was given the full mark specified for this character, while each of the other tested strains took lower units to their qualities.

\section{Results and Discussion}

\section{1-Some vegetative growth aspects in different mango seedling strains}

Shoot length, number of leaves/ shoot and leaf area in the fifteen mango seedling strains namely (first, second, third, fourth, fifth, sixth, seventh, eighth, ninth, tenth, eleventh, twelfth, thirteenth, fourteen and fifteen strain during 2019 and 2020 seasons were listed in Table (2). Shoot length varied from $11.2 \mathrm{~cm}$ in fifth strain in the first season to $20.9 \mathrm{~cm}$ in the thirteenth strain in the second season. It was significantly varied among the fifteen-seedling mango strains the maximum values were recorded to the thirteenth strains. Fifth strain mango recoded the minimum values. These results were true during both seasons. Number of leaves per shoot and leaf area behaved the same trend of shoot length, since the maximum values were recorded in thirteenth strain, while the lowest values were obtained from fifth strain. The great variation on vegetative growth characteristics was mainly attributed to the various responses of these mango srains to horticultural practices, genetic and environmental factors and the suitability of the climatic conditions of Aswan region to some mango seed strain unfitness to the other. These results are in agreement with these obtained by Said (2001); Khattab et al. (2007); Shivanandam et al. (2007); Shaban (2009); Masoud-Amal (2010); Baita et al. (2010); Singh and Bhargava (2011); Reddy et al. (2011); Abourayya et al. (2012); Parshantet al. (2012); Silva et al. (2014) and Fahmy (2016).

\section{2-The leaf chemical components in different mango seedling strains}

There were no significant differences between the fifteen seedling mango strains in some traits of the leaf chemical components namely total chlorophylls, total carotenoids N, P, K, Zn, and $\mathrm{Fe}$ in the leaves. 


\section{3-Percentages of initial fruit set and fruit retention in different mango seedling strains}

Both of initial fruit setting and fruit retention percentages were significantly varied among the fifteen mango seedling strains. Initial fruit set ranged from $3.9 \%$ in fifth strain to $8.1 \%$ in thirteenth strain in season 2019 and from $4.0 \%$ in fifth strain to $8.3 \%$ in thirteenth strain in season 2020. Fruit retention $\%$ of ranged from $0.7 \%$ in fifth strain to $3.0 \%$ in thirteenth strain in the first season of study and from $0.8 \%$ in fifth strain to $3.1 \%$ in thirteenth strain in 2020 seasons. These results are in agreement with those obtained by (Hodaet al., 2003; Nunez and Davenport, 2003; Hassan et al., 2004 and Abd El- Hadi, 2006).

\section{4-Number of fruits / tree and yield per tree in different mango seedling strains}

Data in Table (4) showed that yield expressed in number of fruits / tree and yield (kg.) in the fifteen mango seeding strains during 2019 and 2020. Number of fruits per tree ranged from 196 in fifth strain to 505 fruits in thirteenth strain in the first season of study and from 200 fruits in fifth strain to 512 fruits in thirteenth strain in the second season. The maximum yield $(144.4,148.5 \mathrm{~kg})$ per tree was observed in the thirteen mango seed strain. Fifth strain recorded the lowest yield per tree (37.2, 40.0 kg.) during the two seasons, respectively. These results agree with those obtained by Sukhvibul et al. (2005); Abd El- Hadi (2006); Sharma and Singh (2006); Sweidan et al. (2007); Shaban (2009) and Silva et al. (2014).

\section{5-Fruit weight, height and diameter of fruit in the different mango seedling strains}

Data in Tables $(4,5)$ showed that weight, height and diameter of fruits of the different mango seedling strains during 2019 and 2020 seasons. The weight, height and diameter of fruit significantly varied among the fifteen mango seed strain. The maximum values of fruits weight $(286.0,290.0 \mathrm{~g})$, height $(11.3,11.6 \mathrm{~cm})$ and diameter $(8.5,8.6 \mathrm{~cm})$ were recorded in thirteenth strain. Fifth strain recorded the minimum values. The rest mango seedling strain occupied in between position.

\section{6-Pecentage of peel, seed and pulp of fruit in the different mango seedling strains}

Data in Table (5) showed that peel \%, seed \% and pulp $\%$ in the fruits of the different mango seedling strains during 2019 and 2020 seasons.

\section{6- 1 Fruit peel weight \%}

It was varied from $19.1 \%$ to $16.5 \%$ during both seasons. Fifth strain, fourteenth strain and fifteenth strain gave the highest values. The lowest values $(16.5,16.5 \%)$ were recorded in thirteenth strain during both seasons, respectively.

\section{6- 2 Fruit seed weight $\%$}

It was varied from $20.9 \%$ to 15.8 during both season. Fifth strain, fourteenth strain and fifteenth strain gave the highest values.

The lowest values (16.0, 15.8\%) were recorded in thirteenth strain during both seasons, respectively.

\section{6- 3 Pulp \%}

It was varied from 60.0 to $67.7 \%$ during both seasons. The maximum percentage of pulp was presented in thirteenth strain $(67.5,67.7)$ followed by twelfth strain $(66.3,66.6)$, while the lowest values were recorded ion fifth strain $(60.0,60.0 \%)$ during both seasons, respectively.

\section{7-Fruit quality characteristics in the different mango seedling strains}


Data in Table (6) showed that T.S.S. \%, total acidity $\%$, fibre $\%$, total and reducing sugars $\%$ in the fruits of the different mango seedling strain during 2019 and 2020 seasons.

\section{7- 1 Total soluble solids \%}

It was varied from 12.8 to $17.1 \%$ during both seasons. The maximum values $(16.9,17.1 \%)$ were recorded in thirteenth strain. The lowest values $(12.8,12.9 \%)$ were recorded on fifth strain.

7- 2 Total acidity \%. It was varied from $(0.411$ $, 0.245 \%)$ during both seasons. The maximum values $(0.411,0.408 \%)$ were recorded on fifth strain. The lowest total acidity $\%(0.245,0.250$ $\%)$ were observed in the fruits of thirteenth strain.

\section{7- 3 Total and reducing sugars percentages:}

They were varied significantly according to mango seedling strains was varied from 8.9 to $12.9 \%$ for total sugars and $1.9,5.6 \%$ reducing sugars during both seasons.

The maximum values of total sugars $(12.9,12.9$ $\%)$ and reducing sugars $(5.6,5.6 \%$ ) were recorded in the thirteenth strain. Fifth strain had the lowest values of these sugars \%. Similar results were announced during both seasons.

\section{7- 4 Total fiber \%}

Total fibre \% ranged from $0.74 \%$ to $1.01 \%$ in all mango seedling strains during both seasons. The maximum values $(1.01,0.99 \%)$ were recorded in fifth strain. The lowest values $(0.74,0.74 \%)$ were recorded in thirteenth strain.

The great variation on fruit quality characteristics of the fifteen mango seedling strain might be attributed to the great difference in growth, fruit setting, yield and fruit quality. These results agree with those obtained by Sarkaret al., (2001); Mane et al., (2001), Tandon and Kalra (2001); Sobeih and ElHelaly (2020); Seery (2003); Tawfik (2003), Hassan et al., (2004); and Fahmy (2016).

\section{Numerical evaluation of the mango seedling strains}

Data illustrated in Table (7) showed that the numerical evaluation of the mango seedling strains under study and growing in Aswan governorate, in the average of 2019 and 2020.The data in table 7 showed that, there were great differences in the numerical evaluation, productivity and fruit quality of mango seedlings strains under study. From the ninth to thirteenth strains gave high values compared to the rest of the strains, and their values were 88.2, 95.4, 98.0, 99.0 and 99.5, respectively. Meanwhile, the fourth, fifth, fifteenth, second and first strains gave the lowest values. 
Table (2). Some vegetative growth aspects in the spring growth cycle and pigments (mg/ 1.0 g F.W.) of the studied mango seed strains in 2019 and 2020 seasons.

\begin{tabular}{|c|c|c|c|c|c|c|c|c|c|c|}
\hline \multirow[t]{2}{*}{ Some mango seed strains } & \multicolumn{2}{|c|}{$\begin{array}{c}\text { Shoot length }(\mathrm{cm}) \text { spring } \\
\text { growth cycle }\end{array}$} & \multicolumn{2}{|c|}{$\begin{array}{c}\text { Number of leaves / } \\
\text { shoot }\end{array}$} & \multicolumn{2}{|c|}{ Leaf area $(\mathrm{cm})^{2}$} & \multicolumn{2}{|c|}{$\begin{array}{c}\text { Total chlorophylls (mg/ } \\
1.0 \text { g F.W.) }\end{array}$} & \multicolumn{2}{|c|}{$\begin{array}{c}\text { Total carotenoids } \\
\text { (mg/1.0 g F.W.) }\end{array}$} \\
\hline & 2019 & 2020 & 2019 & 2020 & 2019 & 2020 & 2019 & 2020 & 2019 & 2020 \\
\hline First strain & 13.5 & 13.8 & 10.5 & 11.0 & 65.17 & 66.00 & 4.44 & 4.46 & 1.86 & 1.88 \\
\hline Second strain & 14.7 & 14.5 & 11.7 & 11.5 & 69.10 & 70.00 & 4.36 & 4.50 & 1.91 & 1.78 \\
\hline Third strain & 15.2 & 15.3 & 11.9 & 12.0 & 71.50 & 72.17 & 4.71 & 4.88 & 1.89 & 1.81 \\
\hline Fourth strain & 15.3 & 15.3 & 12.0 & 12.5 & 71.60 & 72.55 & 5.10 & 5.18 & 1.88 & 2.00 \\
\hline Fifth strain & 11.2 & 11.4 & 9.0 & 9.0 & 58.22 & 59.31 & 5.22 & 4.95 & 2.11 & 1.99 \\
\hline Sixth strain & 16.2 & 16.5 & 12.3 & 12.5 & 73.20 & 74.00 & 5.33 & 5.42 & 2.01 & 2.04 \\
\hline Seventh strain & 16.8 & 16.9 & 13.0 & 13.5 & 73.50 & 74.10 & 4.61 & 4.81 & 2.10 & 2.08 \\
\hline Eight strain & 17.0 & 17.1 & 13.5 & 13.5 & 75.10 & 75.18 & 4.71 & 4.84 & 2.22 & 2.18 \\
\hline Ninth strain & 17.6 & 17.8 & 13.6 & 13.7 & 76.00 & 75.80 & 5.13 & 5.22 & 2.23 & 2.25 \\
\hline Tenth strain & 16.8 & 17.0 & 13.2 & 13.4 & 74.20 & 75.00 & 5.04 & 5.13 & 2.11 & 2.19 \\
\hline eleventh strain & 17.5 & 17.5 & 14.0 & 14.5 & 76.00 & 76.11 & 5.19 & 5.22 & 2.11 & 2.09 \\
\hline Twelfth strain & 18.3 & 19.5 & 15.0 & 15.6 & 78.20 & 78.15 & 5.13 & 5.21 & 1.84 & 1.61 \\
\hline Thirteenth strain & 21.0 & 20.9 & 17.0 & 18.0 & 80.10 & 81.66 & 4.50 & 4.61 & 1.81 & 1.86 \\
\hline Fourteenth strain & 11.6 & 11.9 & 9.3 & 9.5 & 61.32 & 61.51 & 5.00 & 4.96 & 1.98 & 1.99 \\
\hline fifteenth strain & 12.2 & 12.6 & 9.9 & 10.0 & 63.13 & 64.20 & 5.18 & 5.22 & 1.99 & 1.99 \\
\hline New L.S.D. at 5\% & 1.9 & 2.0 & 1.6 & 1.7 & 2.01 & 2.08 & Ns & Ns & Ns & Ns \\
\hline
\end{tabular}


Table (3). Leaf content of N,P,K (as \%), Zn and Fe ( as ppm) of the fifteen mango seed strains grown under Aswan region conditions in 2019 and 2020 seasons.

\begin{tabular}{|c|c|c|c|c|c|c|c|c|c|c|}
\hline \multirow[t]{2}{*}{ Some mango seed strains } & \multicolumn{2}{|c|}{ Leaf N \% } & \multicolumn{2}{|c|}{ Leaf P \% } & \multicolumn{2}{|c|}{ Leaf K \% } & \multicolumn{2}{|c|}{ Leaf Zn (ppm) } & \multicolumn{2}{|c|}{ Leaf Fe (ppm) } \\
\hline & 2019 & 2020 & 2019 & 2020 & 2019 & 2020 & 2019 & 2020 & 2019 & 2020 \\
\hline First strain & 1.81 & 1.82 & 0.22 & 0.21 & 1.21 & 1.23 & 42.01 & 42.11 & 48.11 & 48.00 \\
\hline Second strain & 1.81 & 1.81 & 0.20 & 0.21 & 1.20 & 1.19 & 42.18 & 42.22 & 48.11 & 48.23 \\
\hline Third strain & 1.83 & 1.83 & 0.21 & 0.22 & 1.15 & 1.18 & 42.51 & 42.66 & 48.22 & 48.35 \\
\hline Fourth strain & 1.82 & 1.83 & 0.22 & 0.23 & 1.18 & 1.19 & 42.77 & 42.89 & 48.51 & 48.61 \\
\hline Fifth strain & 1.81 & 1.83 & 0.23 & 0.24 & 1.16 & 1.17 & 42.61 & 42.63 & 47.71 & 47.88 \\
\hline Sixth strain & 1.80 & 1.82 & 0.24 & 0.25 & 1.20 & 1.21 & 43.11 & 42.21 & 48.62 & 48.71 \\
\hline Seventh strain & 1.84 & 1.85 & 0.25 & 0.26 & 1.21 & 1.23 & 43.40 & 42.61 & 48.88 & 49.00 \\
\hline Eight strain & 1.86 & 1.85 & 0.24 & 0.24 & 1.20 & 1.21 & 43.11 & 42.55 & 49.01 & 49.22 \\
\hline Ninth strain & 1.86 & 1.85 & 0.26 & 0.24 & 1.22 & 1.21 & 42.71 & 42.80 & 48.31 & 48.38 \\
\hline Tenth strain & 1.86 & 1.87 & 0.23 & 0.25 & 1.19 & 1.20 & 42.91 & 42.99 & 48.44 & 48.56 \\
\hline eleventh strain & 1.81 & 1.82 & 0.26 & 0.25 & 1.18 & 1.18 & 43.09 & 43.18 & 49.00 & 49.09 \\
\hline Twelfth strain & 1.82 & 1.83 & 0.25 & 0.26 & 1.17 & 1.18 & 42.71 & 42.88 & 48.71 & 48.88 \\
\hline Thirteenth strain & 1.84 & 1.85 & 0.27 & 0.24 & 1.22 & 1.23 & 43.11 & 43.36 & 49.01 & 49.23 \\
\hline Fourteenth strain & 1.86 & 1.85 & 0.26 & 0.26 & 1.21 & 1.21 & 42.71 & 42.77 & 48.85 & 48.89 \\
\hline fifteenth strain & 1.85 & 1.86 & 0.24 & 0.25 & 1.19 & 1.21 & 42.78 & 42.91 & 48.88 & 48.91 \\
\hline New L.S.D. at 5\% & Ns & Ns & Ns & Ns & Ns & Ns & Ns & Ns & Ns & Ns \\
\hline
\end{tabular}


Table (4). Yield and yield attributes of the studied mango seed strains grown under Aswan region conditions in 2019 and 2020 seasons.

\begin{tabular}{|c|c|c|c|c|c|c|c|c|c|c|}
\hline \multirow[t]{2}{*}{ Some mango seed strain } & \multicolumn{2}{|c|}{ Initial fruit setting \% } & \multicolumn{2}{|c|}{ Fruit retention $\%$} & \multicolumn{2}{|c|}{$\begin{array}{l}\text { Number of } \\
\text { fruits/tree }\end{array}$} & \multicolumn{2}{|c|}{ Yield/tree (kg.) } & \multicolumn{2}{|c|}{ Fruit weight (g.) } \\
\hline & 2019 & 2020 & 2019 & 2020 & 2019 & 2020 & 2019 & 2020 & 2019 & 2020 \\
\hline First strain & 4.3 & 4.4 & 1.2 & 1.3 & 260.0 & 272.0 & 53.3 & 57.1 & 205.0 & 210.0 \\
\hline Second strain & 4.6 & 4.7 & 1.4 & 1.4 & 284.0 & 290.0 & 62.5 & 62.4 & 220.0 & 215.0 \\
\hline Third strain & 4.7 & 4.8 & 1.5 & 1.6 & 300.0 & 312.0 & 67.5 & 71.1 & 225.0 & 228.0 \\
\hline Fourth strain & 4.9 & 4.9 & 1.8 & 1.9 & 315.0 & 320.0 & 73.4 & 76.5 & 233.0 & 239.0 \\
\hline Fifth strain & 3.9 & 4.0 & 0.7 & 0.8 & 196.0 & 200.0 & 37.2 & 40.0 & 190.0 & 200.0 \\
\hline Sixth strain & 5.0 & 5.1 & 1.9 & 2.1 & 330.0 & 335.0 & 79.2 & 81.1 & 240.0 & 242.0 \\
\hline Seventh strain & 5.6 & 5.8 & 2.1 & 2.3 & 350.0 & 355.0 & 88.2 & 90.2 & 252.0 & 254.0 \\
\hline Eight strain & 5.9 & 6.1 & 2.4 & 2.5 & 378.0 & 380.0 & 98.3 & 98.0 & 260.0 & 258.0 \\
\hline Ninth strain & 6.3 & 6.4 & 2.6 & 2.6 & 390.0 & 390.0 & 102.2 & 101.4 & 262.0 & 260.0 \\
\hline Tenth strain & 6.7 & 7.0 & 2.8 & 2.9 & 412.0 & 418.0 & 109.6 & 112.9 & 266.0 & 270.0 \\
\hline eleventh strain & 7.3 & 7.4 & 2.9 & 2.9 & 422.0 & 430.0 & 114.8 & 116.1 & 272.0 & 270.0 \\
\hline Twelfth strain & 7.8 & 7.9 & 2.9 & 3.0 & 440.0 & 455.0 & 123.2 & 127.4 & 280.0 & 280.0 \\
\hline Thirteenth strain & 8.1 & 8.3 & 3.0 & 3.1 & 505.0 & 512.0 & 144.4 & 148.5 & 286.0 & 290.0 \\
\hline Fourteenth strain & 4.1 & 4.3 & 0.9 & 0.9 & 220.0 & 222.0 & 42.9 & 45.5 & 195.0 & 205.0 \\
\hline fifteenth strain & 4.2 & 4.5 & 0.9 & 1.0 & 230.0 & 230.0 & 48.3 & 48.3 & 210.0 & 210.0 \\
\hline New L.S.D. at 5\% & 0.5 & 0.6 & 0.2 & 0.2 & 11.1 & 11.6 & 9.2 & 9.4 & 4.8 & 5.1 \\
\hline
\end{tabular}


Table (5). Some physical characteristics of fruits of the fifteen mango seed strains grown under Aswan region conditions in 2019 and 2020 seasons.

\begin{tabular}{|c|c|c|c|c|c|c|c|c|c|c|}
\hline \multirow[t]{2}{*}{ Some mango seed strains } & \multicolumn{2}{|c|}{ Fruit length $(\mathrm{cm})}$. & \multicolumn{2}{|c|}{ Fruit width $(\mathrm{cm})}$. & \multicolumn{2}{|c|}{ Peel weight\% } & \multicolumn{2}{|c|}{ Seed weight \% } & \multicolumn{2}{|c|}{ Pulp \% } \\
\hline & 2019 & 2020 & 2019 & 2020 & 2019 & 2020 & 2019 & 2020 & 2019 & 2020 \\
\hline First strain & 8.3 & 8.5 & 6.9 & 7.0 & 18.6 & 18.5 & 19.6 & 19.5 & 61.8 & $62 . .0$ \\
\hline Second strain & 8.6 & 8.8 & 7.1 & 7.3 & 18.4 & 18.3 & 19.5 & 19.2 & 62.1 & 62.5 \\
\hline Third strain & 8.9 & 8.9 & 7.5 & 7.4 & 18.3 & 18.2 & 19.3 & 19.1 & 62.4 & 62.7 \\
\hline Fourth strain & 9.0 & 9.1 & 7.7 & 7.7 & 18.2 & 18.1 & 19.1 & 19.0 & 62.7 & 62.9 \\
\hline Fifth strain & 7.5 & 7.6 & 6.5 & 6.6 & 19.2 & 19.1 & 20.8 & 20.9 & 60.0 & 60.0 \\
\hline Sixth strain & 9.2 & 9.2 & 7.9 & 7.9 & 19.0 & 19.0 & 18.6 & 18.5 & 62.4 & 62.5 \\
\hline Seventh strain & 9.4 & 9.3 & 7.9 & 8.0 & 18.8 & 18.7 & 18.3 & 18.2 & 62.9 & 63.1 \\
\hline Eight strain & 9.6 & 9.5 & 8.0 & 8.1 & 18.6 & 18.5 & 18.1 & 18.0 & 63.3 & 63.5 \\
\hline Ninth strain & 9.6 & 9.7 & 8.2 & 8.2 & 18.4 & 18.3 & 17.7 & 17.6 & 63.9 & 64.1 \\
\hline Tenth strain & 9.8 & 9.9 & 8.3 & 8.3 & 17.8 & 17.2 & 17.4 & 17.3 & 64.8 & 65.5 \\
\hline eleventh strain & 9.9 & 10.6 & 8.4 & 8.3 & 17.6 & 17.5 & 17.2 & 17.0 & 65.2 & 65.5 \\
\hline Twelfth strain & 10.6 & 10.7 & 8.4 & 8.5 & 17.1 & 16.9 & 16.6 & 16.5 & 66.3 & 66.6 \\
\hline Thirteenth strain & 11.3 & 11.6 & 8.5 & 8.6 & 18.5 & 16.5 & 16.0 & 15.8 & 67.5 & 67.7 \\
\hline Fourteenth strain & 7.7 & 7.8 & 6.6 & 6.8 & 19.0 & 19.0 & 20.5 & 20.5 & 60.5 & 60.5 \\
\hline fifteenth strain & 7.8 & 7.9 & 6.7 & 6.9 & 18.8 & 18.7 & 20.1 & 20.0 & 61.1 & 61.3 \\
\hline New L.S.D. at 5\% & 0.2 & 0.3 & 0.1 & 0.2 & 0.8 & 0.7 & 0.7 & 0.6 & 0.9 & 1.0 \\
\hline
\end{tabular}


Table (6). Some chemical characteristics of fruits of the fifteen mango seed strains grown under Aswan region conditions in 2019 and 2020 seasons.

\begin{tabular}{|c|c|c|c|c|c|c|c|c|c|c|}
\hline \multirow{2}{*}{ Some mango seed strain } & \multicolumn{2}{|c|}{ T.S.S.\% } & \multicolumn{2}{|c|}{ Total sugars \% } & \multicolumn{2}{|c|}{ Reducing sugars\% } & \multicolumn{2}{|c|}{ Total acidity\% } & \multicolumn{2}{|c|}{ Crude Fibre\% } \\
\hline & 2019 & 2020 & 2019 & 2020 & 2019 & 2020 & 2019 & 2020 & 2019 & 2020 \\
\hline First strain & 13.6 & 13.8 & 9.5 & 9.6 & 2.4 & 2.5 & 0.370 & 0.366 & 0.96 & 0.95 \\
\hline Second strain & 14.0 & 14.1 & 9.9 & 10.0 & 2.9 & 2.9 & 0.355 & 0.350 & 0.93 & 0.92 \\
\hline Third strain & 14.3 & 14.5 & 10.3 & 10.4 & 3.3 & 3.4 & 0.340 & 0.330 & 0.91 & 0.90 \\
\hline Fourth strain & 14.8 & 15.0 & 10.8 & 10.9 & 3.8 & 3.9 & 0.320 & 0.310 & 0.89 & 0.88 \\
\hline Fifth strain & 12.8 & 12.9 & 8.9 & 9.0 & 1.9 & 2.0 & 0.411 & 0.408 & 1.01 & 0.99 \\
\hline Sixth strain & 15.0 & 15.1 & 11.0 & 11.0 & 3.9 & 3.9 & 0.310 & 0.300 & 0.87 & 0.85 \\
\hline Seventh strain & 15.2 & 15.6 & 11.1 & 11.2 & 4.0 & 4.0 & 0.295 & 0.290 & 0.85 & 0.84 \\
\hline Eight strain & 15.4 & 15.7 & 11.4 & 11.6 & 4.3 & 4.5 & 0.280 & 0.275 & 0.82 & 0.80 \\
\hline Ninth strain & 15.7 & 15.8 & 11.6 & 11.8 & 4.6 & 4.7 & 0.270 & 0.260 & 0.80 & 0.78 \\
\hline Tenth strain & 15.9 & 15.9 & 11.9 & 11.9 & 4.8 & 4.8 & 0.260 & 0.260 & 0.78 & 0.77 \\
\hline eleventh strain & 16.2 & 16.3 & 12.1 & 12.4 & 5.0 & 5.3 & 0.255 & 0.255 & 0.76 & 0.75 \\
\hline Twelfth strain & 16.6 & 16.7 & 12.5 & 12.6 & 5.2 & 5.4 & 0.255 & 0.250 & 0.76 & 0.75 \\
\hline Thirteenth strain & 16.9 & 17.1 & 12.9 & 12.9 & 5.6 & 5.6 & 0.245 & 0.250 & 0.74 & 0.74 \\
\hline Fourteenth strain & 13.1 & 13.2 & 9.2 & 9.3 & 2.2 & 2.3 & 0.398 & 0.379 & 0.98 & 0.98 \\
\hline fifteenth strain & 13.2 & 13.4 & 9.3 & 9.5 & 2.4 & 2.6 & 0.388 & 0.375 & 0.97 & 0.96 \\
\hline New L.S.D. at 5\% & 0.2 & 0.2 & 0.2 & 0.2 & 0.1 & 0.1 & 0.020 & 0.022 & 0.01 & 0.02 \\
\hline
\end{tabular}


Table (7). General score evaluation of fruit of the fifteen mango seed strains grown under Aswan region conditions in the average of 2017 and 2018 seasons.

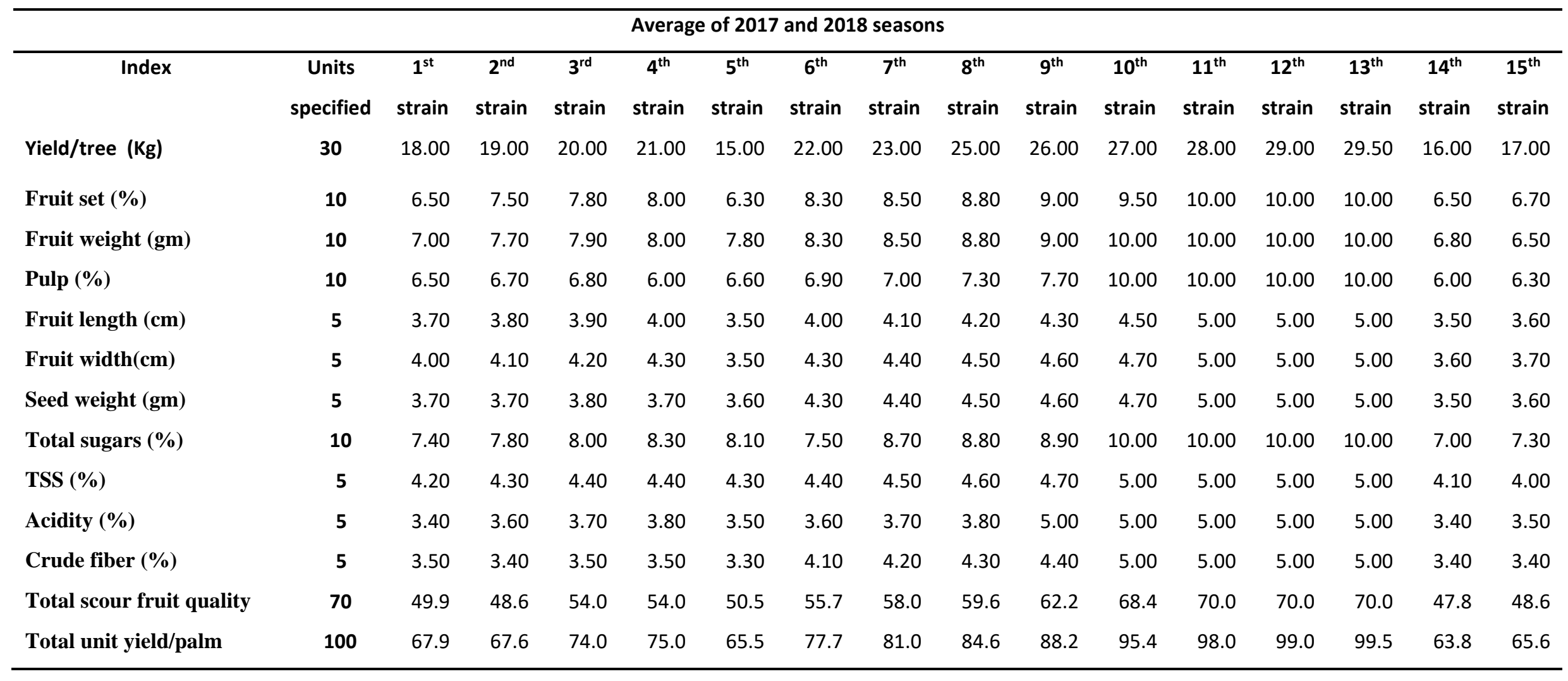




\section{Conclusion}

Fromthe obtained data of such study, there were a promising seedy mango strains in their growth, productivity and fruit quality which grown under Aswan governorate conditions. These seedystrains must be take a lot of care and must be spread their cultivation via vegetative propagation specially grafting.

\section{REFERENCES}

Abd El- Hadi, S.M.K. (2006) 'Evaluation studies on some mango varieties' (M. Sc.) Thesis Al- Azhar Univ. Egypt. P. 166.

Abourayya, M.S., Kassim, N.E., El- Sheikh, M.H. and Rakha, A.M. (2012) 'Evaluation of vegetative growth of Tomy Atkins, Kent and Keitt mango cultivars grown under Nubariya conditions', J. of Applied Sci. Res. (February): 887-895.

Ahmed, F.F. and Morsy, M.H. (1999) 'A new method for measuring leaf area in different fruit species'. Minia J. of Agric. Res. \& Develop. Vol. (19) pp. 97-105.

Annual Reports of Statistical Institute and Agricultural Economic Research in Egypt (2019).

Association of Official Agricultural Chemists (2000) 'Official Method of Analysis (A.P.A.C.) $15^{\text {th }}$ Ed'., Published by A.O.A.C. Washington, D.C. (U.S.A.) pp. 490-510.

Baita, H.U., manga, A.A. and Mustapha, Y. (2010) 'Evaluation of different morphotypes of mango (Mangiferaindica L.) for use as rootstock of mango seedlings production Bayero'. J. of pure and applied Sci. 3 (1): 79-82.
Chapman, H.D. and Pratt , P.P. (1965) 'Method of Analysis for soils, Plants and water' . Univ. of California Division of Agric., Sci., 172-173.

Devilliers, E.A. (1998)'The cultivation of mango', Institute of tropical and subtropical fruits. 28-30.

Fadl, M.S. and Seri El- Deen, S.A. (1978) 'Effect of $\mathrm{N}$ benzyl adenine on photosynthesis pigments and total sugars $\mathrm{n}$ olive seedling growth under saline condition', Res. Bull No. 843- Fac. Agric, Ain Shams Univ. Egypt.

Fahmy, S.H. (2016) 'Evaluation studies on some mango cvs. Under Middle Egypt conditions'. M. Sc. Thesis, Fac. of Agric. Al- Azhar Univ. (Assiut branch).

Galan- Sauco, V. (1993) 'The situation of mango culture $\mathrm{N}$ the world'. Acta Horticulture No. 341, pp. 31-41.

Hamed, A.M. (2012) 'Evaluation of some Arabian date palm cultivars produced through tissue culture grown under Giza condition'. Egypt. J. of Appl. Sci., 27 (4): 144-161.

Hassan, A.M., Giohan, M.A. and Sanaa, B. (2004) 'Maturation and heat Units (G.D.D.) of some mango cultivars'Egypt. J. Appl. Sci., 19 (5B) 553-571.

Hoda, M.N., Singh, S. and Singh, J. (2003) 'Evaluation of ecological groups of mango (Mangiferaindica L.) cultivars for flowering under Bihar conditions'. India J. Agric. Sci. , 73 (2): 101-105.

Khattab, M.M., Hegazy, A.A. and Ezzat, R.M. (2007)'Evaluation of some mango cultivars under East Owainat region'Egypt. J. Appl. Sci. 22 (6A): 198212. 
Kuruom, C.G.R (1967) 'The mango A hand book'. Indian Council of Agric. Res. New Delhi.

Lane, J.H. and Eynon, L.(1965) 'Determination of reducing sugars by means of fehlings solution with methylene blue as indicator'A.O.A.C. Washington D.C/U.S.A. p. 490-510.

Larrauri, J.A. Ruperez, P., Borroto, B, abdSauracalixt, F. (1996) 'Mango peels as a new tropical fiber: preparation and characterization'Lebensmittel-

Wissenschaft, Technologie 29(8): 729733.

Mane, S.A., Sajndranath, A.K. and Narwadkar, P.R. (2001) 'A study on fruit retention in some mango (Mangiferaindica L.) cultivars under parbhbani conditions'. Madras Agric. J. 88 (7/9) 500-502.

Masoud, -Amal, A.R. (2010) 'Evaluation of the productivity of some newly introduction mango cultivars under local conditions'. Thesis, M. Sc. Cairo Univ. Fac. of Agric. Dept. of Pomology, 167 p.

Nunez, E.R. and Davenport, T.L. (2003) 'Effect of leaf, age duration of cool. Temperature treatment and photoperiod $\mathrm{n}$ bud dormancy release and floral initiation in mango'ScentiaHorticulturae, 62., 63-73.

Parshant, B., Rakesh, K., Amit, J. and Wali, V.K. (2012) 'Growth and yield performance of mango varieties under rainfed areas of Jammu'. Indian J. of Agric. Res 46 (3): 281-285.

Reddy, V.S.,Lingaiah, H.B. Krishnappa, K.S., Shankaranarayana, V. Venkataramana, P. and Reddy, M.N.N. (2011)'Evaluation of mango ravieties for the eastern Dry zone of Karnatkamysore', J. of Agric. Sci. 45(1): 107-110.
Said, H.H.M. (2001)'Evaluation of some mango cultivars grown under Aswan conditions'. M. Sc Thesis. Fac. of Agric. Minia Univ. Egypt.

Sarkar, S.K. Gautham, B., Neeraja, G. and Vijaya, N. (2001)'Evaluation of mango hybrids under telangana region of Andhra Pradesh'. Hort. J. 1 (1): 13-21.

Seery, N.K.H. (2003) 'Influence of storage conditions and ripening on marketability and maintaining quality of mango fruit'. Ph. D. Thesis Agric. Sci. Suez Canal Univ. Egypt.

Shaban, A.E.A. (2009) 'Vegetative growth cycles of some mango cultivars in relation to flowering and fruiting, World Journal of Agricultural Sciences; 5 (6)751-759.

Sharma, R.R. and Singh, R. (2006). 'Pruning intensity modifies canopy microclimate, and influences sex ratio malformation incidence and development of fruited panicles in Amrapali mango (Magnifera indica L.)'Sci Hort. Vol. 109 pp. 118122.

Shivanadam, V,N., Shashidhara, V. and Sivappa, (2007)'Growth, flowering and yield behavior of mango varieties and hybride under eastern dry zone of Karnataka'. Environment and Ecoloy; 25 s ( Special ): 1088-1090, gref.

Silva, A.C. da, Souza, A.P. de, Leonel, S. Souza, M.E. de, Ramos, D.P. and Tanaka, A.A. (2014) 'Growth and flowering of five mango cultivar subtropics conditions of Brazil' . American J. of Plant Sci. 5 (3): 393-402.

Singh, L.B. (1960) 'The mango Leonard Hill Books Limited London' pp. 104-142.

Singh, S.K. and Bhargava, R. (2011): Evaluation of mango genotypes of 
morpho- physiological attributes under hotarid zone of Rajasthan, J. of tropical Agric. 49 (1/2) :104-106.

Sobeih, M.E. and El- Helaly, A.A. (2002)'Comparative study on fruit composition of seven mango cultivars at maturity and ripe stage'. J. Agric. Sci. Mansoura Univ. 27 (12): 8211-8219.

Steel, R.G.D. and Torrie, J.H. (1980) 'Principles and procedures of statistics'. MC- Grow Hill Book Co., Singapore, 2Ed 633pp.

Sukhvibul , N. ; Whilety, A.W. and Smith, M.K. (2005) 'Effect of temperature on seed and fruit development in tree mango (Mangiferaindica L.) cultivars'Scientia Hort. Vol. 105, pp. 467-474.

Summer, M.E. (1985) 'Diagnosis and Recommendation integrated System (DRIS) as a Guide of orchard Fertilization'. Hort. Abst. 55(8): 7502.
Sweidan, A.M., Khattab, M.M., Haseeb, G.M. and El- Kheshin, M.A. (2007) 'Evaluation of some mango cultivars under desert conditions at Wadi ElFaregh region Egypt'. Appl. Sci. 22 (8A) : 149-160.

Tandon, D.R. and Kalra, S.K. (2001) 'Ripening early harvested mangoes with Ethrel', Indian, Hort. 146(2): 32-33.

Tawfik, E.S.B. (2003)'Evaluation of some export mango cultivars grown in Egypt'. Ph. D. Thesis. Assiut Univ. Egypt. 187p.

Whiley, A.W. (1992) 'Environmental effect on phenology and physiology of mango'. Acta, Horticulure No. 341, 168-176.

Whiley, A.W. and Scaffer, B, (1997) 'Stress physiology, In Litz, R.E. The mango Boanu production and uses. CAB International, Oxon, UK pp. 147-173. 